Georgetown University Law Center

Scholarship @ GEORGETOWN LAW

2021

\title{
Corporate Adolescence: Why Did “We” Not Work?
}

Donald C. Langevoort

Georgetown University Law Center, langevdc@law.georgetown.edu

Hillary A. Sale

Georgetown University Law Center, has75@georgetown.edu

This paper can be downloaded free of charge from:

https://scholarship.law.georgetown.edu/facpub/2343

https://ssrn.com/abstract=3762718

This open-access article is brought to you by the Georgetown Law Library. Posted with permission of the author. Follow this and additional works at: https://scholarship.law.georgetown.edu/facpub

Part of the Business Organizations Law Commons 


\section{Corporate Adolescence: Why Did "We" Not Work?}

\section{Donald C. Langevoort \& Hillary A. Sale*}

In academic and public commentary, entrepreneurial finance is usually portrayed as a quintessential American success story, an institutional structure whereby expert venture capitalists with strong reputational incentives channel much-needed equity to deserving entrepreneurs, then subject them to intense monitoring to assure they stay on the path to hoped-for success in the form of an initial public offering or public company acquisition. ${ }^{1}$ Thus, it is jarring that in recent years there have been so many troubles, from gross embarrassments to allegations of outright criminality, at companies like Uber, Theranos, and our subject here, WeWork. These dramas are often portrayed in terms of the predictable sins of youthfulness: reckless, disruptive, risk-taking behaviors that come from the volatile interaction of a charismatic young leader and a cult(ure) of STEM-smart followers who buy into the dream. ${ }^{2}$

\footnotetext{
* The authors thank Olivia Brown, Samantha Glazer, Hollie Chenault, Claire Creighton, Jing $\mathrm{Xu}$, and Michael Marcus for their research, insights, and good humor.

${ }^{1}$ E.g., Bernard Black \& Ronald J. Gilson, Venture Capital and the Structure of Capital Markets, 47 J. Fin. Econ. 243 (1997)

2 Among many, see generally Antonio Garcia Martinez, Chaos Monkeys: Obscene Profits AND Random FAilures in Silicon Valley (2016); John CARRYreOU, BAD BlOOD: SeCrets and Lies in Silicon Valley (2018)(about the Theranos scandal); Mike IsSAC, Pumped: The Battle for Uber (2019); Reeves Wiedeman, Billion Dollar loser (2020)(WeWork); Elizabeth Pollman, Private Company Lies, Geo. L.J. (forthcoming, 2021); Steve Blank, When Founders Go Too Far, Harv. Bus. Rev., Nov.-Dec. 2017; Erin Griffith, The Ugly Ethical Underside of Silicon Valley, Fortune, Dec. 28, 2016. On the myths and realities of youthfulness, see Pierre Azoulay et al., Age and High Growth Entrepreneurship, 2 Am. Econ. Rev. Insights 65 (2020); Noam Schreiber, The Shekreli Syndrome: Youthful Trouble, Tech Success, Then a Fall, N.Y. Times, Sept. 14, 2017; Spencer Ante \& Joann Lublin, Young CEOs: Are They Up to the Job?, Wall St. J., Feb. 2012. We wrote this article in the midst of the Covid19 pandemic, which has disrupted all aspects of the economy and society. We express no opinion on what the world of start-ups (or anything else) will be like when the virus finally fades, and recognize that it could force a greater level of maturity in the short run. See Rolfe Winkler, Tech Founders Now Need to Grow Up Fast, Wall St. J., April 18-19, 2020, at B1.
} 
We have no quarrel here with the historical record of success. But the market for start-up capital constantly changes. ${ }^{3}$ We are not the first legal academics to express concern about whether the conventional model is descriptively or normatively suited to today's world, particularly as the period of time from the first capital raise to exit becomes much longer and sources of private capital grow much larger. ${ }^{4}$ This allows some privileged firms (especially the so-called "unicorns"5) to deepen their footprint on society and the economy substantially before taking on the disclosure-oriented obligations of public corporation status. Or maybe never take them on at all. Indeed, while the public and private worlds stay distinct as a matter of law, ${ }^{6}$ the forces of publicness are intruding on the private domain $^{7}$ and raising the risks to recklessness and avoidance.

Our title's metaphorical reference to corporate adolescence is meant to underscore the ever-lengthening period of time, and the resulting temptations without sufficient grown-up supervision, that high-tech start-up companies have before undergoing the so-called rites of passage to public adulthood. ${ }^{8} \mathrm{We}$ argue that this runs the risk of (by failing to lean against) a build-up of bad

3 See Josh Lerner \& Ramana Nanda, Venture Capital's Role in Financing Innovation: What We Know and How Much We Still Need to Learn, 34 J. Econ. Persp. 237, 253 (2020)("Understanding why traditional venture capital contractual provisions have faded in importance and their social welfare implications appears to be a promising area of future research for both theorists and empiricists alike," pointing to some of the high-profile scandals noted earlier).

${ }^{4}$ See Elizabeth Pollman, Startup Governance, 168 U. Pa. L. Rev. 155 (2019); Jennifer S. Fan, Regulating Unicorns: Disclosure and the New Private Economy, 57 B.C. L. Rev. 583 (2016); Usha Rodrigues, The Once and Future Irrelevance of Section 12(g), 2015 U. Ill. L. Rev. 1561; Michael D. Guttentag, Patching a Hole in the JOBS Act, How and Why to Rewrite the Rules that Require Firms to Make Periodic Disclosures, 88 Ind. L. Rev. 151 (2013); Donald C. Langevoort \& Robert B. Thompson, Publicness in Contemporary Securities Regulation after the JOBS Act, 101 Geo. L.J. 337 (2012).

${ }^{5}$ See Keith Brown \& Kenneth Wiles, The Growing Blessing of Unicorns, 32 J. App. Corp. Fin. 52 (2020).

${ }^{6}$ See Robert B. Thompson \& Donald C. Langevoort, Redrawing the Public-Private Boundaries in Entrepreneurial Capital Raising, 98 Cornell L. Rev. 1573 (2013).

7 See Donald C. Langevoort, The Effects of Shareholder Primacy, Publicness, and "Privateness" on Corporate Cultures, 43 Seattle U. L. Rev. 377 (2020). On publicness generally, see Hillary A. Sale, J.P. Morgan: An Anatomy of Corporate Publicness, 79 Brook. L. Rev. 1629 (2014).

${ }^{8}$ See also Renee M. Jones, The Unicorn Governance Trap, 166 U. Pa. L. Rev. Online 165, 166 (2017). There is a strand of literature on the "mature" start-up, however, this appears simply to refer to firms well along the pre-public growth curve, not the behavioral context. E.g., Abraham J.B. Cable, Fool's Gold: Equity Compensation and the Mature Start-up, 11 Va. L. \& Bus. Rev. 613 (2017). 
choices and testy behaviors commonly observed in human adolescents, e.g., risk-taking and rule-breaking, thereby embedding in the firm's habits and culture problems that may later be hard to fix. This is especially true when the founders themselves are young and prone to immature behavior, though we do not so limit our attention. There is rhetorical expression of the problem in familiar memes like "fake it "til you make it" and "move fast and break things."

To explore all this, we borrow an approach from business school case studies. ${ }^{9}$ We tell the WeWork story in some detail, not simply because it is interesting (which it is) but because it starkly poses a question that manyinvestors, board members, lawyers, and regulators, among others-will find difficult to answer. How could this happen as against all the high-powered incentives and smart-money discipline that supposedly exists in venture finance ${ }^{10}$ And what if anything could or should have been done differently, particularly by way of corporate governance? By itself, WeWork is just an anecdote, and to an extent an aberration. But toggling back and forth between narrative and analysis, our article makes the case that start-up adolescence is both an apt metaphor and real cause for concern.

We do not try to resolve all this normatively, content mainly with showing the interplay of conflicts in start-up financing that lead to the prediction that the situation is a persistently risky one, where the risks and costs fall on less sophisticated investors, retail and institutional, and with unfortunate spillovers to the capital markets generally. Insistence on private ordering has a dark side. So we point with some frustration to the recent pushes by Congress and the SEC to increase the number of retail investors eligible to invest in this space, in the name of "opportunity" that is more likely to turn into opportunism.

\section{The WeWork StOry, Part 1}

\footnotetext{
9 For a case study involving legal ethics in the context of the Theranos scandal, see Gautam Hans, How and Why Did It Go So Wrong?: Theranos as a Legal Ethics Case Study (May 29, 2020). Georgia State University Law Review, Forthcoming 2021, available at SSRN: https: / / ssrn.com/abstract $=3613443$.

${ }^{10}$ See Pollman, supra note 4 ("If VCs are strong monitors, why are examples of oversight failures so plentiful and varied?").
} 
A dreamer who envisions co-working office space on Mars, and a man raised by a women's collective in Oregon. ${ }^{11}$ They were the builders of WeWork - literally. Adam Neumann was a schemer, who persuaded longtime real estate moguls and Silicon Valley funders, who "didn't do real estate," to support the company. Miguel McKelvey was part architect, part schemer, and a hands-on builder. In 2019, McKelvey was the Chief Culture Officer and Neumann was the Chief Executive Officer of a Series H Unicorn with a valuation of $\$ 47$ Billion. ${ }^{12}$ In 2020, Neumann was out as CEO, and the private valuation was down to $\$ 7.3$ billion. ${ }^{13}$ By March of 2020, the valuation was at $\$ 2.9$ billion and by June, McKelvey had stepped down as well. ${ }^{14}$

WeWork began when Adam Neumann rented out part of the office space he was using in a Brooklyn office where he was selling high-end baby clothes. In an effort to cut costs, he rented out a corner of his office to someone he found on craigslist. Shortly thereafter, Neumann looked at another building with his landlord, Joshua Guttman. Neumann proposed a co-working idea, with a shared profit. Guttman bit, and Neumann then approached McKelvey about the idea. Green Desk was the outcome - and the predecessor to WeWork, though it was decidedly different from what WeWork would become. ${ }^{15}$

Despite fears about the economy, the company opened in 2008, and the idea took off. ${ }^{16}$ Later, Neumann and McKelvey sold their share of the business to Guttman for $\$ 3$ million dollars to be paid over several years. In 2011, they used cash from the sale, credit cards, and loans from friends, to relocate the concept to SoHo, and opened the first office of what was to become the WeWork model. Neumann then sent "free" plane tickets to friends in Israel

11 Alex Konrad, Inside The Phenomenal Rise Of WeWork, Forbes (Nov. 5, 2014), https://www.forbes.com/sites/alexkonrad/2014/11/05/the-rise-ofwework/\#6a557b606f8b.

${ }^{12}$ Sophia Kunthara, From Hot to Not: A Timeine of WeWork's IPO Implosion, Crunchbase (Oct. 1, 2019 https://news.crunchbase.com/news/from-hot-to-not-a-timeline-of-weworks-ipoimplosion/. Indeed, just one year earlier, the company had the third largest startup valuation, after Uber and Airbnb.

13 Lauren Feiner, SoftBank values WeWork at $\$ 2.9$ billion, down from $\$ 47$ billion a year ago, CNBC (May 18, 2020), https://www.cnbc.com/2020/05/18/softbank-ceo-callswework-investment-foolish-valuation-falls-to-2point9-billion.html.

${ }_{14}$ Deirdre Bosa, WeWork co-founder Miguel McKelvey is leaving at the end of the month, CNBC (June 5, 2020), https://www.cnbc.com/2020/06/05/wework-co-founder-miguel-mckelvey-is-leavingat-the-end-of-the-month.html.

${ }^{15}$ Konrad, supra note 11.

${ }^{16}$ Konrad, supra note 11. 
who thought they were coming to the States for fun, and who ended up working seven days a week, doing the construction build out. ${ }^{17}$

By 2012, WeWork had multiple locations and big aspirations. Neumann spoke publicly about expanding technology, but when asked how or why, he did not have an answer. This is notable, because such statements, in a publicly traded company, can be the root of class action claims for liability. ${ }^{18}$ Nevertheless, the company continued to grow and to raise private money. In January 2012, WeWork raised \$6.85 million from friends and family; \$17 million in a Series A in July, 2012; \$40 million in a Series B in May, 2013; and $\$ 150$ million in a Series C in February, 2014. ${ }^{19}$ These numbers were about double the size of the average Series rounds in the same timeframe. ${ }^{20}$

The Series C round was particularly notable because the company attracted the attention of Benchmark, one of Silicon Valley's most well-known venture capital funds. ${ }^{21}$ Because Benchmark had not done real estate before, its leader flew to New York to vet the concept and see firsthand why WeWork was different from other shared office space concepts. Sold on Neumann's vision, Benchmark valued the company at $\$ 100$ million and then, when the investment bank Jefferies joined, the valuation increased to $\$ 450$ million. Shortly thereafter, McKelvey pitched Jared Kushner and won a prize spot as an anchor tenant in a Dumbo project. ${ }^{22}$

In the same timeframe, the adolescent side of WeWork was increasingly becoming public - and receiving press coverage. For example, in 2012, the

\footnotetext{
${ }^{17}$ Konrad, supra note 11.

${ }^{18} 17$ C.F.R. $\S 240.10 b-5$.

${ }^{19}$ Dylan Tweney, WeWork raises $\$ 355 M$ at nearly $\$ 5 B$ valuation, plans IPO, VentureBeat (Dec. 15, 2014), https://venturebeat.com/2014/12/15/wework-raises-355m-at-nearly-5bvaluation-plans-ipo/.

${ }^{20}$ Average seed capital in 2012 was $\$ 1.7$ million; average series A in 2012 was 9.2 million; average series B in 2013 was 17.2 million. https://techcrunch.com/2019/04/25/a-quicklook-at-how-fast-series-a-and-seed-rounds-have-ballooned-in-recent-years-fueled-by-topinvestors/. The average series C in 2014 was $\$ 26$ million. https://tech.co/news/muchfunding-raise-round-2015-05).

${ }^{21}$ Konrad, supra note 11.

${ }^{22}$ Konrad, supra note 11. Neumann, a former Israeli soldier, reportedly assisted longtime friend Kushner in the development of a video promoting peace in the Middle East. According to Vanity Fair, Neumann asked WeWork development director Roni Bahar to find an advertising firm to create "a slick video for Kushner that would showcase what an economically transformed West Bank and Gaza would look like." Gabriel Sherman, You Don't Bring Bad News to the Cult Leader: Inside the Fall of WeWork, Vanity Fair (Nov. 21, 2019), https://www.vanityfair.com/news/2019/11/inside-the-fall-of-wework.
} 
company started taking entrepreneurs and employees to camp, and in 2014, the New York Times went along. ${ }^{23}$ The family of Adam Neumann's wife, Rebekah Paltrow Neumann, owns a summer camp in the Adirondacks, and the company used it for several years. The culture at camp, which echoed that of the company was, well, adolescent. The goal was networking and "a change of pace." ${ }^{24}$ There was neither reliable cellphone service nor Wi-Fi. Instead, hookahs, vintage typewriters, and canoes loaded with beer were aplenty." ${ }^{25}$ Marijuana was not provided but was in "abundance."

In 2014, at the time when Benchmark was considering investing additional funds, one 31-year old entrepreneur at camp was wearing tattoos on his face and body and holding Super Soaker Water Guns filled with vodka. He stated that he was "getting into as much trouble as humanly possible." Another man also carrying a Super Soaker, "declared to the crowd, 'If you don't want to see me naked, don't go to camp.' Another had turned his free camp T-shirt into a crop top and said, 'We're gonna bro out so hard.'” Then, he noted that the camp had a "different vibe than... the city or even the Hamptons, ... [where] you still have a certain level of internal restraint."26

Restraint and WeWork, however, did not go hand-in-hand. Neumann roamed the office in bare feet. The company offered unlimited free beers to employees and tenants at all hours of the day. Neumann also loved Don Julio tequila and would persuade employees to take shots of it at 2 a.m. meetings. ${ }^{27}$ Marijuana at work was common, as was dancing around fires in the woods on the weekends. ${ }^{28}$ Neumann even "installed an infrared sauna and a cold plunge pool in his Manhattan office." ${ }^{29}$

Despite the adolescent antics, the funding continued. Indeed, a few months after the 2014 New York Times camp article appeared, in December

\footnotetext{
${ }^{23}$ Marisa Meltzer, WeWork Goes to Summer Camp, The New York Times, (Sept. 5, 2014), https://www.nytimes.com/2014/09/07/fashion/wework-goes-to-summer-camp.html.

${ }^{24}$ Meltzer, supra note 23.

${ }^{25}$ Meltzer, supra note 23.

${ }^{26}$ Meltzer, supra note 23.

${ }^{27}$ Amy Chozick, Adam Neumann and the Art of Failing $U_{P}$, The New York Times (May 18, 2020), https://www.nytimes.com/2019/11/02/business/adam-neumann-wework-exitpackage.html.

${ }^{28}$ Chozick, supra note 27.

${ }^{29}$ Chozick, supra note 27.
} 
2014, WeWork raised $\$ 355$ million in a Series D offering. ${ }^{30}$ It was still not profitable but was valued at $\$ 5$ billion. The investors included big names: Goldman Sachs and JP Morgan, and the press reported that an initial public offering (IPO) was likely in the next few years. ${ }^{31}$

Although Neumann compared the company to Uber and Airbnb, both of which were in the "sharing" economy, WeWork's model was riskier, because WeWork actually owned or leased the office space that people shared. ${ }^{32}$ The liability, so to speak, belonged to WeWork. Even before the COVID-19 pandemic, the success of the business model depended on WeWork's continued ability to service long-term leases on real estate by renting out office space at a higher price on a short-term lease. The model also relied upon continued demand for cramped office space where people work elbow-toelbow. At the time of the Series D, of course, money for entrepreneurs was flowing and making it possible for them to afford the rent, but the key question was what would happen to the business model when the bubble burst and WeWork still had all that property. ${ }^{33}$

As we will see, the bubble did burst - when publicness intervened. But not before WeWork did a Series E (\$444 M), F (\$690 M), G (\$4.4 B), and H $(\$ 1 \mathrm{~B}) .{ }^{34}$ All of these fundraising rounds were delineated as "late stage," and all are significant in size. None raised eyebrows. Instead, initially skeptical investors (JP Morgan) lined up for opportunities, and Masayoshi Son of Softbank jumped on board with the Series G and had a wild and expensive ride. ${ }^{35}$

\footnotetext{
${ }^{30}$ Lindsay Gellman and Eliot Brown, WeWork: Now a $\$ 5$ Billion Co-Working Startup, WALL ST. J. (Dec. 15, 2014), https://www.wsj.com/articles/wework-now-a-5-billion-real-estatesartup-1418690163.

${ }^{31}$ Tweney, supra note 19.

${ }^{32}$ Issie Lapowsky, Believe It: Co-Working Space Startup WeWork Is Now Worth $\$ 5 B$, Wired (Dec. 16, 2014), https://www.wired.com/2014/12/wework-valuation/.

${ }^{33}$ Lapowsky, supra note 31.

${ }^{34}$ Sophia Kunthara, WeWork May Reduce Its Valuation Ahead of IPO By Tens of Billons, Crunchbase (Sept. 5, 2019), https://news.crunchbase.com/news/wework-may-reduce-its-valuationahead-of-ipo-by-tens-of-billions/.

${ }^{35}$ Katrina Brooker, WeFail: How the Doomed Masa Son-Adam Neumann relationship set WeWork on the road to Disaster, Fast Company (Nov. 15, 2019), https://www.fastcompany.com/90426446/wefail-how-the-doomed-masa-son-adamneumann-relationship-set-wework-on-the-road-to-disaster.
} 
The story of Mr. Son's investment is apparently "famous." 36 Neumann spent only 12 minutes with Son touring the WeWork headquarters before reaching agreement on a $\$ 4.4$ billion investment - an investment for which Mr. Son's son has expressed regret. ${ }^{37}$ Then, Neumann hopped into his white Mercedes Maybach and, while his chauffeur drove, listened to rap and enjoyed the win. ${ }^{38}$ Many say that this investment and the opinion of Son, that Neumann should take on even more wild ideas, is part of what led to the WeWork downfall. ${ }^{39}$ But, as Part III will reveal, the board, the bankers, and others all played a role.

After the Softbank investment, Neumann's grandiosity accelerated. He wanted to be the world's first trillionaire. He wanted to be president of the world. ${ }^{40}$ He started WeLive, a concept for short term apartment rentals - but framed them as places that would "drive down suicide rates because "no one ever feels alone."'41 He described the WeGrow school and a plan to "shelter the world's orphans" and "give them a family, the WeWork family." "2 "There was talk of a WeBank, WeSail, WeSleep, an airline." ${ }^{33}$ And still the money came in and talk of an IPO grew.

The IPO, however, was the financial undoing of WeWork. The antics and choices, the burn rate, the conflicts of interest, and the lack of hope for profitability all became public - though not until after the bankers had floated a huge valuation with an "incoherent prospectus" and were forced to pull it back. ${ }^{44}$ The business model, long-term leases on real estate that was renovated and rented with short term leases, i.e., no long run predictability of revenues, was always flawed. Initial valuations for the IPO were in the $\$ 40$-50 billion range and even when dropped to $\$ 10$ billion, the company discovered it had no buyers. $^{45}$ This was the point at which publicness met WeWork and its governance choices head on.

\footnotetext{
${ }^{36}$ Chozick, supra note 27.

${ }^{37}$ Feiner, supra note 13.

${ }^{38}$ Chozick, supra note 27.

${ }^{39}$ Brooker, supra note 35.

${ }^{40}$ Chozick, supra note 27.

${ }^{41}$ Chozick, supra note 27.

${ }^{42}$ Chozick, supra note 27.

${ }^{43}$ Chozick, supra note 27.

${ }^{44}$ Chozick, supra note 27.

${ }^{45}$ Joshua Franklin and Anirban Sen, WeWork delays IPO after frosty investor response, Reuters (Sept. 16, 2019), https://www.reuters.com/article/us-wework-ipo/wework-delays-ipoafter-frosty-investor-response-idUSKBN1W12T6.
} 
Although the wheels came off the WeWork bus at the time of the IPO, the seeds of its crash were planted much earlier. The culture inevitably produced allegations like those at Uber, of discrimination and a "frat-boy culture." ${ }^{\text {"6 }}$ Neumann's Chief of Staff claimed she was demoted and fired for being pregnant and raising concerns about Neumann turning the company jet into a "hotbox," filled with marijuana smoke. ${ }^{47}$ Another lawsuit included claims of sexual assault at a work event and groping at the summer camp. ${ }^{48}$ According to the complaint, both incidents were reported to HR and neither resulted in discipline to the men involved. ${ }^{49}$ The company later stated, without admitting anything, that such behavior would not be tolerated, but the problem was that the "culture" of WeWork was the product of the corporate adolescence and cult of personality our "regulatory" regime has promoted.

WeWork grew because it was the beneficiary of the "private" offering regime and a tech/Unicorn bubble in which the market encouraged companies with huge burn rates and behavior that, in the public space, would not have been acceptable. When the venture capital investors, who had put more than $\$ 12$ billion into WeWork, wanted to cash out and Masa Son's cash infusions stopped, "Neumann was blindsided." It appears that although he may not have understood the potential for the party to stop, he did understand the value of the privilege with which he was operating. But, without cash to support the burn, Neumann who "never wanted to go public ... and wanted to remain private so he could do whatever the f--- he wanted," yielded to the pressure to go public - or at least try to do so. ${ }^{50}$

Unfortunately for Neumann, the market's interest in and tolerance for companies based on ideas that might generate cash but not profits had waned. Uber's offering was a huge disappointment to investors. ${ }^{51}$ Another company with a culture of corporate adolescence, Uber had faced a series of scandals

${ }^{46}$ Gaby Del Valle, WeWork's "frat-boy" culture enables sexual harassment, new suit claims, Vox (Oct. 12, 2018), https://www.vox.com/the-goods/2018/10/12/17969190/weworklawsuit-sexual-assault-harassment-retaliation.

47 David Yaffe-Bellany, WeWork's Ousted C.E.O. Adam Neumann is Accused of Pregnancy Discrimination, The New York Times (Oct. 31, 2019), https://www.nytimes.com/2019/10/31/business/wework-neumann-discriminationcomplaint.html.

${ }^{48}$ Del Valle, supra note 46.

${ }^{49}$ Complaint, Bardhi v. WeWork, EEOC (Oct. 31, 2019), http://www.wigdorlaw.com/wpcontent/uploads/2019/10/Bardhi-v.-WeWork-Filed.pdf

${ }^{50}$ Sherman, supra note 22 .

${ }^{51}$ Maureen Farrell, 2019 the Year of IPO Disappointment, WaLl ST. J. (Dec. 29, 2019), https://www.wsj.com/articles/2019-the-year-of-ipo-disappointment-11577615400. 
that, because its founder, Travis Kalanick retained control, had been consistently ignored - that is, until the company's board finally bowed to publicness and pressure. A venture capital director who had made sexist comments resigned, Kalanick was pushed out (and paid off), and a new CEO, with a strong positive and public company reputation, Dara Khosrowshahi, was installed. ${ }^{52}$

Khosrowshahi's job was to clean up Uber's and manage the company through an IPO. ${ }^{53}$ He did so, but with mixed results. He began with apologies and statements about the commitment to a changed culture, one that would not tolerate sexual harassment and law breaking in the core of the business. ${ }^{54} \mathrm{He}$ used words like "trust" and stressed the choices the company was now making to, arguably, grow up and understand its publicness and social license. Although the scandals played a significant role in the pressure a cultural shift, both Uber and WeWork craved cash. Cash is king in a company with a high burn rate, and as the private money dries up, IPO pressure increases. Eventually, Khosrowshahi did take Uber public, but the private "value" of the company never materialized. The offering price, $\$ 45.00$ per share, was well below the company's private valuations, and before the pandemic hit, Uber's stock was trading only at $\$ 41.00$ per share. ${ }^{55}$

Whether the same will be true for WeWork remains to be seen. ${ }^{56}$ Its attempted IPO failed in a very public fashion, resulting in considerable media coverage about the adolescent antics of its founders, its conflicted structure, and the lack of corporate governance controls, to which we return in Part III.

\section{The Potential Pathologies of Start-Up Capital Raising}

\footnotetext{
${ }^{52}$ Evan Mills, A Short history of the Many, Many Ways Uber Screwed Up, Wired (June 21, 2017), https://www.wired.com/story/timeline-uber-crises/. Mike Isaac, With Uber's I.P.O., Dara Khosrowshahi is Taking Travis Kalanick's Company Public, The New York Times (May 3, 2019), https://www.nytimes.com/2019/05/03/technology/uber-ipo-ceo-darakhosrowshahi-travis-kalanick.html.

${ }^{53}$ Isaac, supra note 52.

${ }^{54}$ Yaffe-Bellany, supra note 47.

${ }^{55}$ Mike Isaac, Michael J. de la Merced, and Andrew Ross Sorkin, How the Promise of a \$120 Billion Uber I.P.O Evaporated, The New York Times (May 15, 2019), https://www.nytimes.com/2019/05/15/technology/uber-ipo-price.html.

${ }^{56}$ WeWork remains an operating company with considerable presence in the shared office space marketplace, but without the mythology that drove its ambitions. What we describe here is a financial implosion, not (yet) its failure as a going concern.
} 
The WeWork story shows what can happen within the domain of corporate adolescence, but not whether it is commonplace enough to worry deeply about. Surely most start-ups are not so immature. And even if it the risk of such behavior is worrisome, the conventional venture finance narrative predicts that it should be self-correcting: bad experiences like these will teach funders a lesson that they would be foolish not to learn from, and their reputational interests will incentivize them to take interest. We pause here to address these two arguments.

When VCs finance a high-potential start-up, they only fund enough to get the company moving toward success, ${ }^{57}$ at which point the start-up must obtain a second round of financing, mostly from new sources of money, and then a third, and so-on. (Seven or eight rounds would not be unusual today.) There is a high-powered incentive to make it up each step of the ladder, with regular scrutiny of the value of the firm at this still early stage. The founders feel this sharply; so do the funders who have sunk so much money at an earlier round. With growing evidence of success, the founders and early funders can hold onto more of the enterprise; with troubles, that may be hard. Those investors who have tied their fortunes to the founder do not want to mess with what appears (in myth or reality) to be the firm's best shot.

\section{A. Behavioral Agency Costs}

1. Edgy Behavior

Our quick overview of high-tech start up financing gives ample reason to explain why founders will often find themselves shading the truth to stand out. The initial pitch requires aggressive claims of an ability to achieve promised results; after that, their feet are to the fire through the search for new rounds of investment. The risk of failure is palpable - most start-ups do not survive the gauntlet.

57 On how they do this, see Paul Gompers et al., How Do Venture Capitalists Make Decisions?, 135 J. Fin. Econ. 169 (2020). 
The temptation to dissemble in such high-stakes, high-expectations environments would be natural for most people and most organizations. ${ }^{58}$ "Motivated inference" is the general phenomenon by which people exploit the moral wiggle-room of ambiguity about both reality and expectations - reality in terms of the enterprise being pitched, expectations about what to say or do (or not say or do). Early stage ventures reek of uncertainty, which can support inflated optimism that may be in good faith, but not necessarily warranted. ${ }^{59}$ Gradually, and down a very slippery slope of self-deception along with the deception of others, representations about the venture's progress take on a life of their own. ${ }^{60}$ If there are conscious doubts about the project in its early stages, ambiguity about disclosure norms can provide comfort. Many people feel justified in leaving out troubling details from a statement otherwise technically true, even though half-truths are fraudulent as a matter of law. ${ }^{61}$ This is where the perception (if not reality) of prevailing norms can be summoned to duty for good cause, project success. Some version of "everyone does it" enables those with brilliant hopes and dreams to fake it with the expectation that all will be forgiven or forgotten when they make it.

Certain situational pressures abundant in start-ups increase the likelihood of dishonesty. ${ }^{62}$ Loss aversion is the tendency to take greater risks to avoid losing what they possess relative to what they would take when seeking to gain precisely the same thing; once started and financed, threats are filtered through a loss frame. Cognitive stress and physical tiredness make misrepresentation more likely. What starts out as innocent becomes a trap as the adverse consequences of telling the truth grow.

\footnotetext{
${ }^{58}$ See Yuri Mishina et al, Why Good Firms Do Bad Things: The Effects of High Aspirations, High Expectations and Prominence on the Incidence of Corporate Illegality, 53 Acad. Mgt. J. 701 (2010). 59 This can take the form of conscious rationalization by entrepreneurs (see Elizabeth Pollman, Private Company Lies) or a more pernicious form of self-deception whereby the entrepreneur is firmly convinced of the rightness, and righteousness, of what he or she says or thinks. See Donald C. Langevoort, Selling Hope, Selling Risk: Corporations, W All Street and the Dilemmas of InVestor Protection 26-28, 38-42 (2016).

${ }^{60}$ For an in-depth explanation,, see Vasilis Theoharakis et al., Going Down the Slippery Slope of Legitimacy Lies in Early Stage Ventures: The Role of Moral Disengagement, J. Bus. Ethics (2020). ${ }^{61}$ See Todd Rogers et al., Artful Paltering: The Risks and Rewards of Using Truthful Statements to Mislead Others, 112 J. Pers. \& Soc. Psych. 456 (2017); see also Christina Bicchieri et al., It's Not a Lie If Your Believe the Norm Does Not Apply: Conditional Norm Following with Strategic Beliefs, https://ideas.repec.org/p/ppc/wpaper/0012.html (2019).

${ }^{62}$ See Theoharakis et al., supra; for further discussion of ethics in the start-up arena, see Jared Harris, Ethics and Entrepreneurship, 24 J. Bus. Vent. 407 (2009); Robert Cressey et al., Entrepreneurship, Governance and Ethics, 95 J. Bus. Ethics 117 (2010).
} 
That much applies to just about anybody in those circumstances. ${ }^{63}$ But those who choose to become entrepreneurs have dispositions that can make them more susceptible than most. A body of specialized research exists about entrepreneurial psychology, suggesting that start-up founders have greaterthan-normal tendencies toward self-efficacy, self-assurance, autonomy, power and independence. ${ }^{64}$ They are often highly intense and creative "think outside the box" people. And even though each of these traits is an attractive one in terms of who we think of as likely to succeed, each is also associated with a higher risk of the kind of ethical risk-taking referred to earlier. Danny Miller, a noted organizational psychologist who focuses on entrepreneurs, refers to this as the "Janus face" problem. ${ }^{65}$ The adulation of the good face obscures the heightened risk of the bad. In other words, the hyper-creative looks outside the lines for opportunities and so discovers value; he (or less likely, but not impossibly, she) also ignores lines that are not supposed to be crossed. ${ }^{66}$ Somewhat provocatively, one econometric study of entrepreneurs suggests a combination of high cognitive ability and a history of illicit adolescent behavior correlates with later success in this rough and tumble world. ${ }^{67}$

\section{Youth}

If entrepreneurs are generally more disposed toward risky behaviors, then the young entrepreneurs who have such a claim on the public's fascination presumably inhabit an even higher behavioral risk category. To be clear, we are not claiming that young founders dominate the start-up world. One study shows that the average age of a successful founder is in the early to mid-40s, often after one or more unsuccessful tries. ${ }^{68}$ But the authors of that study acknowledge that young founders are a significant presence in the start-up

${ }^{63}$ See Scott Rick \& George Loewenstein, Hypermotvation, 45 J. Consumer Res. 645 (2008).

${ }^{64}$ Many of these can be bundled into what is the most widely recognized bias of successful business people, overconfidence. See David Hirshleifer, Are Overconfident CEOs Better Innovators, 67 J. Fin. 1457 (2012); LANGEVOORT, supra, at 27.

${ }^{65}$ Danny Miller, A Downside to the Entreprenurial Personality?, 39 Entrepreneurship: Theory and Practice 1, 2 (Jan. 2015)

${ }^{66}$ See Francesca Gino \& Dan Ariely, The Dark Side of Creativity, 102 J. Pers. \& Soc. Psych. 445 (2011).

${ }^{67}$ See Ross Levine \& Yona Rubenstein, Smart and Illicit: Who Becomes an Entrepreneur and Do They Earn More?, 132 Q.J. Econ. 963 (2017)( "[e]ven as teenagers, those who incorporate later in life tend to score higher on learning aptitude tests, exhibit greater self-esteem, and engage in more illicit activities than other people”).

${ }^{68}$ Azoulay et al., supra 
world and may be even preferred by many venture capitalists. They generate a powerful mythology.

Entrepreneurs in their 20s and early 30s are, presumably, more likely than their elders to exhibit the kinds of adolescent and post-adolescent behaviors common generally-more impulsive, norms-challenging, and aggressive, only gradually becoming more mature. Those given millions of dollars in early-round funding have their self-esteem validated before ever having struggled to success, and are prone to compensate for the reality that they may be in over their head with grandiose expressions of self-efficacy. Putting aside for a moment their VC handlers on the board of directors, they are likely to be surrounded by similarly young cohorts, with a resulting echo chamber in terms of exuberance and confidence. If given a long (or no) leash, they may be especially creative, intense and motivated, but undisciplined. Not having much in the way of experience to draw from in knowing which lines are meant to be challenged or not, they may convince each other that all lines are suspect or to be ignored.

Because of the closed-in, secretive nature of early stage ventures, this is a hard proposition to test empirically. With respect to public companies, CEO age is associated with a higher risk appetite among males ${ }^{69}$ and greater competitiveness. ${ }^{70} \mathrm{CEO}$ behavior (on the job and private), in turn, has a viral effect on the rest of the team of employees, signaling that ethical aggression is indeed the way to get ahead. ${ }^{71}$ In other words, the youthful organization as a whole is arguably more susceptible to inflated entitlement precisely because of its collective naiveté.

\section{Gender}

By all accounts, the world of high-tech start-up capital-raising has a diversity problem, including massive gender inequality. Stories of hostile work environments abound. Despite evidence that female start ups are more

\footnotetext{
${ }^{69}$ Matthew Serfling, CEO Age and the Riskiness of Corporate Policies, 25 J. Corp. Fin. 251 (2014); Jarrko Peltomaki et al., Age, Gender and Risk-taking: Evidence from S\&P 500 Executives, https://papers.ssrn.com/sol3/papers.cfm?abstract_id=2547516.

70 See Yim, The Acquisitiveness of Youth, CEO Age, and Acquisition Behavior, $108 \mathrm{~J}$. Fin. Econ. 250 (2013); Maurice Levi et al., Deal or No Deal: Hormones and the M\&A Game, 56 Mgt. Sci. 1452 (2010)(using CEO age as proxy for male hormone-driven behavior).

${ }^{71}$ See Lee Biggerstaff et al., Suspect CEOs, Unethical Culture, and Corporate Misbehavior, $117 \mathrm{~J}$. Fin. Econ. 98 (2015). On off-the-job behavior, see Why Boards Should Worry About Executives Off-the-Job Behavior, Harv. Bus. Rev., Jan.-Feb. 2020, at 17; Tom Lin, Executive Private Misconduct, 88 G.W. L. Rev. 327 (2020).
} 
successful than those of their male counterparts, ${ }^{72}$ in 2017, for example, venture capitalists put thirty-five times the money into male-founded start-ups than female founded; the number of male founded start-ups financed was sixteen times the number of female founded firms. ${ }^{73}$ The venture capital industry itself is heavily male dominated. The reasons are many, no doubt, for this situation. While there is some evidence showing willingness to hear diverse pitches ${ }^{74} \mathrm{VCs}$ may well be using stereotypical heuristics for deciding what constitutes promise - mental images of the aggressiveness and single-minded intensity it takes to succeed that generate a natural gender bias in funding choices. ${ }^{75}$ The gross gender imbalance in an industry where connections and networks matter is bound to be self-perpetuating, and change slowly. And the supply of talented women is truncated by stereotypes and bias all along the career progression, so that the pool of women entrepreneurs is smaller than it should be.

Whatever the precise cluster of reasons for the bias, male domination is likely to amplify the risky and aggressive traits and behaviors predicted above. By some combination of hormones and role socialization, men are more likely to cheat than women, a tendency that grows larger in group settings. From this, one might presume that early stage start-ups too often offer, among many other things, an intense male bonding experience that trumps truth-telling.

\section{B. Downstream Agency Costs}

In the conventional account of start-up finance, $\mathrm{VC}$ and other funders bargain for sufficient control rights to enable close monitoring for risky behaviors by founders and their teams. There is ample evidence of founders

\footnotetext{
${ }^{72}$ See Katie Abouzahr, Matt Krentz, John Harthorne, and Frances Brooks Taplett, "Why Women-Owned Startups Are a Better Bet," Boston Consulting Group (June 6, 2018), https://www.bcg.com/publications/2018/why-women-owned-startups-arebetter-bet (finding that startups founded and co-founded by women generated 78 cents for every dollar while those founded by men produced only 31 cents per dollar).

73 See Will Gornall \& Ilya Strebulaev, Gender, Race and Entrepreneurship, April 2020, https://papers.ssrn.com/sol3/papers.cfm?abstract_id=3301982. One argument in favor of a liberalized crowdfunding exemption was that the "crowd" would be more open to diversity in founders of start-ups. There is some evidence to support that hope as to women founders. See Schwartz, supra.

74 Gornall \& Strebulaev, supra.

${ }^{75}$ See Kamal Hassan et al., How the VC Pitch Process is Failing Female Entrepreneurs, Harv. Bus. Rev., Jan. 13, 2020, https://hbr.org/2020/01/how-the-vc-pitch-process-is-failingfemale-entrepreneurs.
} 
being deposed as CEOs by funder-dominated boards. ${ }^{76}$ So in theory, the tendencies described above should be kept in check.

But that depends on funder bargaining power at each stage of financing, and by many accounts, the last decade (at least) has been marked by a shift in power to the founder. There are more non-traditional sources of capital to compete with the well-known VC firms, placing considerable limitations on what they can demand from founders with good ideas. ${ }^{77}$ Neither VCs nor private equity funders want a reputation for being overbearing, which might hurt when competing for the next hot deal. ${ }^{78}$ New money sloshes around over the course of all the financing rounds, a reason start-ups can stay private longer to capture as much of the upside potential as possible for founders and early funders before exit.

This leads to mixed incentives, especially (as with SoftBank and WeWork) later investors are willing not only to buy new rounds of equity from the issuer but also let earlier funders cash out in the same transaction. Monitoring via internal controls can be costly, which is of concern because start-ups tend to be cash poor and motivated to spend precious capital on that which demonstrates tangible progress. Better governance devices might seem a luxury early on, especially to entrepreneurs new to the business world, and quickly become a form of deferred maintenance.

There are also mixed incentives that come from the frequent revaluations that come with each new round of financing. Start-ups are naturally hard to value because they are so speculative, which is problematic in and of

\footnotetext{
${ }^{76}$ That said, one reason given for $\mathrm{VC}$ preference for youthful founders is that they might not drive as hard a bargain out of inexperience. See Azoulay et al., supra.

${ }^{77}$ Many investors that once participated in venture capital via investments in venture capital funds now invest directly, which they treat as a major disruption of conventional venture finance. Lerner \& Nanda, supra note 3, at 244, 252. One major change has been the growth in size and influence of corporate venture capital (i.e., captive funds deployed via investments in start-ups that could benefit the corporate owner of the fund in various ways). See Jennifer Fan, Catching Disruption: Regulating Corporate Venture Capital, 2018 Colum. Bus. L. Rev. 341, 376 (noting the proliferation of new sources in the form of "tourist investors"). 78 Lerner \& Nanda, supra note 3, at 252 ("This pattern [of founder friendly behavior] has been especially true in the last few years, given the proliferation of non-traditional investors such as SoftBank, sovereign wealth funds, and corporations. In an intensely competitive market, some venture capital firms may be tempted to pitch entrepreneur-friendly contracts to founders in an attempt to get access to the most attractive deals. . . Reflecting this competition, venture capital groups may have chosen to outdo each other in the extent of their hospitality to company founders").
} 
itself since relative power and control rights shift at each funding round. That creates an incentive to the creation of good news and the suppression of bad, which need not necessarily suggest fraud but, as discussed earlier, biased perceptions. Whether VCs or other early stage funders have an incentive to expose risks and shortfalls via heavy monitoring is questionable, suggesting some slack. Knowing too much can be dangerous. Sophisticated later stage funders will understand this, but may nonetheless be limited by competitive pressures from the increasingly diverse funding sources, especially at the later stages. With larger and larger sums of money in the hands of competing later round funders like private equity firms, hedge funds and even mutual funds, bidding wars can ensue to reveal who has the most optimistic (not realistic) valuation - the so-called winner's curse. There is no good way of betting against the company on the short-side, as there is in more well-developed financial markets. ${ }^{79}$ Bubbles cam result that no one has a strong incentive to pop by looking too closely for misbehavior in the face of apparent progress.

We leave to others further exploration of the directly conflicting interests among founders and multi-round funders that this valuation uncertainty produces, and the wide array of contractual responses. ${ }^{80}$ The less well-appreciated conflicts story, among legal academics at least, faces in a different direction: the conflicts (and incentive to inflate values) arising from the relationship between funders and their own upstream suppliers of capital. Nearly all the funders, from VC to later round funders, are themselves managing other peoples' money. ${ }^{81}$ The VC, for example, will have a set of limited partners - institutions like pension funds, university endowments, etc. - who contribute most of the capital to be invested it a range of start-ups, hoping for a few big scores. The fund manager is compensated with sizable

\footnotetext{
${ }^{79}$ See Jesse Fried \& Jeffrey Gordon, The Valuation and Governance Bubbles of Silicon Valley, https://clsbluesky.law.columbia.edu/2019/10/10/the-valuation-and-governancebubbles-of-silicon-valley/

${ }^{80}$ See Pollman, supra note 4. In the WeWork story, it was notable that SoftBank's large later stage investment came with a rachet clause that promised to increase its equity in the event of an exit at a lower valuation than anticipated at the time of its investment, protecting it at the expense of other funders. See John C. Coffee, Jr. Toxic Unicorns, https://clsbluesky.law.columbia.edu/2019/11/06/toxic-unicorns-what-has-been-

missed-about-weworks-fiasco/, Nov. 6, 2019. Coffee observes that this dilution of others was not clearly disclosed even in the public offering documents filed with the SEC.

${ }^{81}$ On the conflicts and incentives associated with managed investment portfolios generally, see James Spindler, How Private is Private Equity and at What Cost?, 76 U. Chi. L. Rev. 311 (2009); Luigi Zingales, The Future of Securities Regulation, 47 J. Acct'g Res. 391 (2009); John Morley, The Separation of Funds and Managers, 123 Yale L.J. 1228 (2014); Anita Krug, Downstream Securities Regulation, 94 B.U. L. Rev. 1589 (2014).
} 
fees, often combining on-going management fees and high-powered incentive fees. The asset base on which the periodic fees are calculated is based on current valuations - commonly, the price set at the latest round. In this sense, the VC gets a tangible payoff from an inflated valuation even if, later on, the bubble deflates. In a widely-noted article published recently, two financial economists criticized the industry for basing reported valuations on the most recent round's price without adjustment for the special rights and privileges of pre-existing classes - a practice that they say inflates later-round private share values by nearly $50 \%$ compared to a more rigorous econometric method. ${ }^{82}$ In a recent SEC advisory, the staff observed that failures to value private funds' holdings in accordance with the disclosed valuation process have led to overcharging management fees and carried interest based on inappropriately overvalued holdings. ${ }^{83}$

Just as concerning are the effects of bubbles on the attraction of investors to new funds being sponsored by the VCs and later-round asset managers. These portfolio managers should be somewhat disciplined by the fact that they raise new rounds of capital as earlier portfolios age out - the failure to achieve real returns, not just inflated valuations, should be noticed by savvy investors looking for talented money managers. That discipline does exist for highly reputable funds that cater to savvy investors. ${ }^{84}$ But not all sources of private capital seem to figure that out, and so there are opportunities to new fundraising to high points in valuation, and of obscuring actual performance at the end of a fund's run so that comparative success or failure is hard to parse out by any but the most astute. ${ }^{85}$ The emergence of mutual funds, with large numbers

82 Will Gornall \& Ilya Strebulaev, Squaring Venture Capital Valuations with Reality, 135 J. Fin. Econ. 120 (2020), discussed in Yves Smith, Fake Valuations are Running Roughshod Over the Venture Capital Industry, New York Magazine, Nov. 14, 2018, https://nymag.com/intelligencer/2018/11/fake-unicorns-are-running-over-the-venturecapital-industry.html.

83 The SEC's Office of Compliance, Inspections and Examinations recently issued a list of the kinds of conflicts of interest it has observed, including valuation biases. Risk Alert: Observations from Examinations of Investment Advisers Managing Private Funds, June 23, 2020, at https://www.sec.gov/files/Private\%20Fund\%20Risk\%20Alert_0.pdf.

${ }^{84}$ See Gregory Brown et al., Do Private Equity Funds Manipulate Reported Returns?, 132 J. Fin. Econ. 267 (2019) (demonstrating incentive of lower reputation funds to distort earnings, but suggesting that on average they do not success due to investor sophistication).

${ }^{85}$ On the incentives to obscure directed at those who invest in venture capital, see Indraneel Chakraborty \& Michael Ewens, Managing Performance Signals through Delay: Evidence from Venture Capital, 64 Mgt. Sci. 2473 (2018); in private equity funds, see Brad Barber \& Ayako Yasuda, Interim Fund Performance and Fundraising in Private Equity, 124 J. Fin. Econ. 172 
of retail investors, as major funders has underscored this particular problem because they are constantly in search of new money. ${ }^{86}$

We have only scratched the surface here, hopefully enough to add to the list of reasons why heavy monitoring might be in decline and the conventional monitoring model of venture finance under stress. Presumably, sophisticated upstream suppliers of capital will understand the conflicts, seek out the intermediaries with good reputations, and insist on transparency and protection. But less diligent investors will increasingly be subject to attraction to segments of the private markets via sales savvy as much or more than evidence of skill and loyalty, ${ }^{87}$ so that the conflicts of interest become all the more pernicious. ${ }^{88}$ How this works out in contemporary venture financing is still only dimly understood because of lack of transparency, but surely raises doubts about the assumption that upstream investor diligence offers a dependable check on founder overreaching as funders become more diverse in interests and incentives, and compete with each other for the allotments they lust over for more reasons than appear at first glance.

\section{WeWork PART 2: Culture Of CONFLicts}

We now resume our case study of WeWork, where the hypermotivation and agency costs associated with corporate adolescence appeared to contribute to the culture of conflicts and the lack of internal controls. From the self-interested transactions, to the taking of corporate

(2017); Ludovic Phalippou, Beware of Venturing into Private Equity, 23 J. Econ. Perspectives 147 (2009).

${ }^{86}$ See Jeff Schwartz, Should Mutual Funds Invest in Start Ups?: A Case Study of Fidelity Magellan Fund's Investments in Unicorns and Other Start-ups and the Regulatory Implications, 95 N.C. L. Rev. 1341 (2017); Serge Chernenko et al., Mutual Funds as Venture Capitalists? Evidence from Unicorns (NBER working paper, 2017). The SEC recently proposed a good faith rule on the valuation of private investments by mutual funds. Good Faith Determinations of Fair Value, IC33845 (April 21, 2020).

${ }^{87}$ On the wide variety of financial products that straddle the line between public and private, see Sun Eun (Summer) Kim, Typology of Public-Private Equity, 44 Fla. St. L. Rev. 1435 (2017). ${ }^{88}$ Of particular concern here are public pension funds, whose asset managers may be insulated from competitive pressures. See William Clayton, Public Investment, Private Funds and State Law, Baylor L. Rev. (forthcoming, 2020). Clayton points to SEC doubts about investor diligence in private equity, citing Speech by Andrew Borden, Spreading Sunshine in Private Equity, May 6, 2014, https://www.sec.gov/news/speech/2014-spch05062014ab.html; see also note - supra. 
opportunities, to the personal loans and nepotism, the array of conflicts was considerable and implicated not just Neumann and his family but members of the board and the investment bankers.

Neumann embodied all of the adolescent characteristics described in Part II. He was bold, young, and male, and he had conflicts of every sort. He owned stakes in buildings leased to WeWork. ${ }^{89}$ He sold the trademark "We," to the company for $\$ 6$ million dollars. ${ }^{90}$ He had voting control over the company, and his wife had control over his replacement. ${ }^{91}$ He was allowed to "sell and borrow more than $\$ 1$ billion dollars against his WeWork stake."92

The corporate adolescent culture also allowed for the masking of conflicts as creativity. Consider WeGrow, the school the Neumanns built, with WeWork money, to educate their own children. Whether through action or inaction, the board acquiesced in WeGrow, a school that had nothing to do with the business of the company - unless that nurturing the entrepreneurial spirit of elementary school children connects to the core of an office leasing company. Rebekah was the CEO and opened WeGrow at WeWork headquarters in the fall of 2018. The for-profit school cost $\$ 42,000$ per year and offered yoga, mindfulness, Spanish, Mandarin, and Hebrew. ${ }^{93}$ Like all WeWork projects, this one had its quirks, including that although parents were allowed into the family waiting room, nannies were required to wait outside. Why? Apparently because Rebekah Neumann did not want her nannies inside. ${ }^{94}$ In short, “"The whole thing was about her and what was right for her children,' a person close to the school said." 95 Indeed, when the Neumanns relocated to San Francisco

\footnotetext{
${ }^{89}$ We Co., Registration Statement Under the Securities Act of 1933 (Form S-1) 200 (Aug 14, 2019) [hereinafter We Co. Registration Statement].

${ }^{90}$ Eliot Brown, WeWork's Long List of Potential Conflicts Adds to Questions Ahead of IPO, WALL ST. J.(Sept. 6, 2019), https://www.wsj.com/articles/weworks-long-list-of-potentialconflicts-adds-to-questions-ahead-of-ipo-11567808023?mod=article inline; We Co. Registration Statement, supra note 89, at 199.

${ }^{91}$ We Co. Registration Statement, supra note 89, at 197-98.

${ }_{92}$ Maureen Farrell and Eliot Brown, The Money Men Who Enabled Adam Neumann and the WeWork Debacle, WALL ST. J. (Dec. 14, 2019), https://www.wsj.com/articles/the-moneymen-who-enabled-adam-neumann-and-the-wework-debacle-11576299616.

${ }^{93}$ Sarah Ashley O'Brien, WeWork's school, where kids farm, learn Hebrew and Mandarin, CNN Business (Oct. 30, 2018), https://www.cnn.com/2018/10/30/tech/wework-schoolwegrow/index.html.

${ }^{94}$ Sherman, supra note 22.

${ }^{95}$ Sherman, supra note 22.
} 
in the winter of 2019, they took a teacher from WeGrow with them - a conflict within a conflict. ${ }^{96}$

Neumann also borrowed from the company - repeatedly. At one point, the total seemed to be over $\$ 740$ million tied to his shares in the company. ${ }^{97}$ He also had a low-interest loan from the company for $\$ 380$ million that allowed him to exercise stock options early. ${ }^{98}$ If the company had been public, this loan would have been illegal - as a result of the IPO issues and other excesses that led to the Sarbanes Oxley Act in 2002.99

In addition, the company employed lots of "Neumanns." Rebekah was CEO of WeGrow and the Chief Brand and Impact Officer at WeWork. ${ }^{100}$ Her brother-in-law was the Chief Product Officer. ${ }^{101}$ Adam's brother-in-law ran the fitness part of the company. ${ }^{102}$ The company also regularly used contractors and vendors owned by executives. ${ }^{103}$ And, the parents of the Vice-Chair of the real estate division, were the real-estate brokers on a building lease in Miami. ${ }^{104}$ Indeed, "[a]t an executive retreat in Montauk on Long Island, Mr. Neumann once raised a glass in a toast 'to nepotism," further exhibiting the total lack of controls or even appreciation for them. ${ }^{105}$ No doubt, the nepotism contributed to the echo chamber of entitlement and confidence.

The board and investors also allowed Neumann to do something generally frowned upon in startups - when new money came in, Neumann sold his own stock and reaped profits. ${ }^{106}$ He also restructured the company's voting stock in order to continue to maintain control. ${ }^{107}$ Bruce Dunlevie, from Benchmark, pushed back, arguing that "absolute power corrupts absolutely."108

\footnotetext{
${ }^{96}$ Sherman, supra note 22.

${ }^{97}$ Brown, supra note 90.

${ }^{98}$ We Co. Registration Statement, supra note 89, at 51, 199.

${ }^{99}$ Sarbanes-Oxley Act $\S 402$, 15 U.S.C.S. $§ 78 m$ (2002).

${ }^{100}$ We Co. Registration Statement, supra note 89, at 172, 197.

${ }^{101}$ Brown, supra note 90.

102 Brown, supra note 90.

${ }^{103}$ Brown, supra note 90 . We had a lease with a building in Miami owned by the brother of Arash Gohari, co-head of real estate.

${ }^{104}$ Brown, supra note 90.

${ }^{105}$ Farrell and Brown, supra note 92.

${ }^{106}$ Farrell and Brown, supra note 92.

${ }^{107}$ When T Rowe price invested, Neumann restructured stock so his shares had 10 times the votes of normal shares. See Farrell and Brown, supra note 92.

${ }^{108}$ Farrell and Brown, supra note 92.
} 
Despite those concerns, the board voted unanimously to allow both the voting stock change and the stock sales.

Neumann's voting control, like that of Mark Zuckerberg, Travis Kalanick, and others, meant that he had the power to oust dissenting voices on the board. The early board had four people, ${ }^{109}$ but even as it grew with new investors, rising to nine by the time of the S-1, the culture of conflicts and Neumann's voting power remained. The directors gave Neumann that power, but risked losing their seats and a view of the company in which they were invested - even though their legal role was as fiduciaries for the company and the other shareholders.

The conflicts were not limited to Neumann. Indeed, the terms "related parties" or "related party" appeared more than 100 times in the prospectus the company filed. ${ }^{110}$ Consider the board member conflicts. WeWork employed the son of John Zhao, from the investor Hony Capital. ${ }^{111}$ Dunlevie's daughter was also an employee. ${ }^{112}$ Lew Frankfort, the former CEO of Coach, Inc., "borrowed from WeWork to buy stock and exercise some stock options early -- a move typically made to save on taxes." ${ }^{113}$ Steve Langman's private equity group became a co-manager of the WeWork real-estate fund business and earned management fees and profits on any properties purchased. ${ }^{114}$ Then, when WeWork expanded its own involvement in the real-estate fund business, and Rhone's stake decreased, WeWork gave him restricted shares to make up for the changed business model. ${ }^{115}$ In short, the culture bred conflicts at all

109 The early board members were: Adam Neumann, Bruce Dunlevie (July 2012 Benchmark), Steven Langman (May 2013 - Rhone), Lew Frankfort (July 2014). In September 2019: September 2019: Adam Neumann, Bruce Dunlevie, Steven Langman, Lewis Frankfort, John Zhao (added 2016 - Hony Capital), Mark Schwartz (March 2017 former VC at Goldman), Ron Fisher (Nov 2017 - Softbank), Frances Frei (2019 - HBS Professor).

${ }^{110}$ We Co. Registration Statement, supra note 89.

${ }^{111}$ Farrell and Brown, supra note 92.

${ }^{112}$ Farrell and Brown, supra note 92.

${ }^{113}$ Farrell and Brown, supra note 92; We Co. Registration Statement, supra note 89, at 207.

${ }^{114}$ Konrad Putzier, Investor's Ties to WeWork Raise Conflict-of-Interest Concerns, Wall ST. J. (Aug. 27, 2019), https://www.wsj.com/articles/investors-ties-to-wework-raise-conflictof-interest-concerns11566903601\#: : :text=Langman's\%20company\%2C\%20Rhone\%20Group\%2C\%20runs ,Co.\%2C\%20and\%20the\%20landlord.

${ }^{115}$ We Co. Registration Statement, supra note 89, at 206. 
levels, and because investors and board members alike were involved, no one had an incentive to say no.

The money continued to flow and so did the acquisitions and business decisions - arguably unrelated to the business of WeWork and certainly unchecked by the board. The core business of WeWork was real estate, but it bought an event planning business, a search engine optimization company, and a coding school. ${ }^{116}$ Neumann made an offer for the salad company, Sweetgreen, Inc., and as noted before, opened WeGrow. ${ }^{117}$ The directors apparently raised concerns about the disparate choices, but the company kept spending on unrelated companies - with tacit, if not explicit, board approval.

Also, without board intervention, Neumann lavished money on an executive suite, building an exercise room and adding a sauna and ice bath to his offices in New York and San Francisco. He used the company jet for personal trips, when he decided to buy a top-of-the-line Gulfstream jet, the directors acquiesced - even though investors, like T. Rowe Price complained and told "management and the board that it had grown sour on the company."118 T. Rowe Price then sold off as much stock as it could in the SoftBank transactions. ${ }^{119}$

Throughout all of these transactions, the directors, who had a voice and could have, for example, made noisy exits, continued to enable the scheme and hope for an IPO. Why? Because they had money in the company, and they believed the public markets would provide both an exit and a necessary check on Neumann. As a result, Schwartz, Dunlevie, and Langman urged Neumann to commit to an IPO, but Softbank and Neumann resisted - at least until Softbank's own investment value plunged. ${ }^{120}$

The banks also played a role. Just like at Enron, the bankers had been developing relationships with Neumann, hoping for the IPO. They had earned fees on the private offerings and were invested in the company, but now, millions of dollars in IPO fees were around the corner, and Neumann's selfprescribed "personal banker," 121 Jamie Dimon and Goldman Sachs were

\footnotetext{
${ }^{116}$ Farrell and Brown, supra note 92; We Co. Registration Statement, supra note 89, at 35.

${ }^{117}$ Farrell and Brown, supra note 92.

${ }^{118}$ Farrell and Brown, supra note 92.

${ }^{119}$ Farrell and Brown, supra note 92.

${ }^{120}$ Farrell and Brown, supra note 92.

${ }^{121}$ Farrell and Brown, supra note 92. JPMorgan led a $\$ 500$ million credit line to Mr. Neumann and lent another $\$ 97$ million in other forms of debt, largely mortgages with low rates on his many homes. We Co. Registration Statement, supra note 89, at 216.
} 
onboard. They provided no check or balance, drafting a prospectus that was subject to derision for its wacky language and valuations that the market immediately rejected as unsupported by a company that had turned a profit only once - many years prior. Investors also revolted against the "string of conflicts." 122

Indeed, according to the Financial Times, the investment banks vying for the IPO pitched Neumann with valuation numbers based on nothing more than "teenage exuberance." Proposals ranged from $\$ 46$ to $\$ 63$ billion (JP Morgan), $\$ 61$ to $\$ 96$ billion (Goldman Sachs), and $\$ 43$ to $\$ 104$ billion (Morgan Stanley). ${ }^{123}$ Yet, when the public spoke, WeWork had to ratchet down its expectations, pulling the offering when the valuation was trending toward $\$ 15$ billion, or more than $\$ 30$ billion below the valuation at the time of the last Softbank infusion.

The underwriting arm of the banks, of course, had already earned millions in fees and stood to gain much more on the public offering as well as loans they planned to structure. JP Morgan had loaned Neumann, in his personal capacity, hundreds of millions of dollars, including for the buildings that he bought and then leased back to WeWork. Indeed, the role of the banks in WeWork, its "growth", and its IPO has been described as "enabling," to be distinguished from evaluating, checking, balancing, or even providing healthy skepticism. ${ }^{124}$

As IPO hopes deflated, and in an attempt to stem controversy and complaints, Neumann searched for more money and added a woman to the board - without consulting the other directors. When they found out, they "vented" about it at a board meeting, where typically, Neumann was not present. Later, Neumann apologized and said he would change his ways. ${ }^{125}$ Nevertheless, he pushed back on the governance changes his bankers said were necessary for the IPO - acceding when desperation prevailed. Neumann then agreed to: the appointment of a lead independent director by the end of the year, a 50 percent decrease in his voting rights, and the elimination of the

\footnotetext{
${ }^{122}$ Banks had warned Neumann the conflicts would be a problem. Farrell and Brown, supra note 92 .

${ }^{123}$ Andrew Edgecliffe-Johnson, Eric Platt, James Fontanella-Khan, and Laura Noonan, WeWork turmoil puts spotlight on JPMorgan Chase and Goldman Sachs, Financial Times (Sep. 24, 2019), https: / /www.ft.com/content/272d408e-de40-11e9-b112-9624ec9edc59.

${ }^{124}$ Farrell and Brown, supra note 92.

${ }^{125}$ Farrell and Brown, supra note 92.
} 
provision allowing his wife to select his successor. ${ }^{126}$ It was, however, too little, too late.

The interest in the offering was insufficient, and calls for Neumann to step down grew. Even Mr. Son's representative board members understood that Neumann had to go. Indeed, investors and executives at companies backed by Softbank urged Son to move against Neumann. ${ }^{127}$ Finally, Dimon told Neumann he had to choose - IPO or CEO. ${ }^{128}$

For Neumann, the choice was clear. If he didn't step down, the IPO would not happen. There would be no cash, and his stake would be worthless. At first, he agreed to relinquish his CEO title but not voting control, but to do so, he demanded payment, and Softbank bought him out with a consulting fee and stock purchases. Then, the board forgave $\$ 1.75$ million in funds he owed to WeWork for personal travel and other expenses. ${ }^{129}$ When the offering failed outright, the board switched its focus to saving the company.

Ironically, reflecting on the process many months later, Goldman's CEO, David Solomon, indicated that the public process was key to the demise of WeWork and that the private process was to blame. Speaking on a Unicorn panel at Davos in January of 2020, Solomon stated, "One of the things that I've said publicly... is the process actually worked around WeWork." ${ }^{130}$ In an IPO, the banks are faced with a private company with numbers that are not public and must work with the company to see whether the model works - before setting an actual public market value. According to Solomon, the vetting occurs when, ultimately there's a diligence process, there's a proving out process, there, at times, are meetings with investors beforehand, and that process grounds to reality." ${ }^{\prime 31}$ The WeWork process, he said, worked, even if it "might not have been as pretty as everybody would like it to be." 132 As he noted, part of the issue is that private companies are also "not held to the same

\footnotetext{
${ }^{126}$ Farrell and Brown, supra note 92.

${ }^{127}$ Farrell and Brown, supra note 92.

${ }^{128}$ Farrell and Brown, supra note 92.

${ }^{129}$ Farrell and Brown, supra note 92.

${ }^{130}$ Oscar Williams-Grut, Goldman Sachs CEO defends work on failed WeWork IPO, Yahoo! Finance (Jan. 21, 2020), https://finance.yahoo.com/news/davos-2020-unicorns-wework-ipodavid-solomon-stacey-cunningham-goldman-145306829.html.

${ }^{131}$ Williams-Grut, supra note 130.

${ }^{132}$ Williams-Grut, supra note 130.
} 
standard around producing information" as their public counterparts, ${ }^{133}$ arguably causing distortions like those in Uber, Theranos and WeWork.

Importantly, missing from these statements is a recognition, let alone ownership, of Goldman's contribution to this "private” adolescence. Goldman and the other banks provided funding to WeWork, series after series, along the way, enabling every choice of Neumann. At each series, the banks had the power to set the valuation and the opportunity to demand better information from the company. Yet, only when faced with the public regime, their own potential for strict liability, and the market rejection of an arguably ridiculous, if not false, prospectus, that they were forced to recalibrate and withdraw the offering.

IV. Private Privileges, Enabling Boards, ANd Fiduciary Deficits

Start-up financing occurs under a set of exemptions, some longstanding, others more recent - that remove the disclosure obligations required in public markets on the assumption that private ordering suffices. ${ }^{134}$ This exemptive privilege, in turn, assumes that the parties to the sequential rounds of financing will be faithful agents, i.e., fiduciaries, to their own sources of capital. Where there are conflicts of interest, fiduciary deficits will arise unless either the threat of litigation for breaches of duty sufficiently deters the resulting opportunism or the sources of capital are themselves sufficiently watchful and savvy to combat the opportunism. As sources of private capital become more numerous and diverse, as suggested in Part II, the latter may not happen so reliably.

By all accounts, WeWork's extraordinary growth over eight rounds of financing strengthened Neumann's hand and concealed ample danger signs. In the absence of required disclosure, fiduciary duties take on extra significance. We understand that the board was limited in its power once Neumann took his super-voting rights, and lost more maneuvering room when Softbank opened its checkbook with what seemed to be blind faith in Neumann leadership. There is still a cautionary story about governance failure. This Part thus turns to the role of the WeWork board of directors in this story.

\footnotetext{
${ }^{133}$ Williams-Grut, supra note 130.

${ }^{134}$ See, e.g., Virginia E. Harper Ho, Nonfinancial Risk Disclosure \& The Costs of Private Ordering, 55 AMERICAN BUSINESS LAW JOURNAL 407.
} 


\section{A. The Culture of Conflicts and an Enabling Board}

Consider the simple controls built into the fiduciary duties of directors and officers and how they were designed to address these issues. Duties of candor, obligations surrounding conflicts of interest and corporate opportunities, and requirements for conscious choices (whether "good" or "bad") should mediate agency costs. Those duties are about loyalty, good faith, and oversight, and all were at issue in the WeWork story, where the board enabled conflicts, was controlled by Neumann, and neglected the investors and stakeholder employees who funded it.

The boards are missing in the WeWork saga and those of its "peers." With each additional funding round, while WeWork's paper valuation grew, the mechanisms for control did not. When Masayoshi Son told Adam Neumann to spend faster, Neumann did so, and the directors failed to ask questions and question answers. ${ }^{135}$ The company grew, the nature of the investors changed, but the leaders did not grow up. Instead, they went to summer camp and drank tequila shots, seemingly stuck in adolescence, while the board watched but did not engage. ${ }^{136}$ In doing so, the board abdicated its most important responsibility: to make, not avoid, decisions, thus violating duties of care and loyalty, including good faith. There are many complicated reasons for these failures, which Elizabeth Pollman has detailed - contracts around or embedding conflicts, investor outs, and ratchets to name a few. ${ }^{137}$ Her premise, with which we do not quibble, is that startup governance problematizes corporate governance norms. ${ }^{138}$ It does not, however, eliminate the duties - just the internal controls those duties impose and create.

In short, good faith and the disclosure discourse inherent in it is designed to play a role in establishing internal controls - even in startups and problematically, with longer term corporate adolescents. Recall Mark Schwartz's statements at WeWork's board meeting on October 3, 2019,

\footnotetext{
${ }^{135}$ Brooker, supra note 35.

${ }^{136}$ Eliot Brown, How Adam Neumann's Over-the-Top Style Built WeWork. 'This Is Not the Way Everybody Behaves.', WALL ST. J. (Sept. 18, 2019) https://www.wsj.com/articles/this-isnot-the-way-everybody-behaves-how-adam-neumanns-over-the-top-style-built-wework11568823827.

${ }^{137}$ Pollman, supra note 4. See Coffee, supra note 80. Coffee describes how WeWork's ratchet clause was primarily held by principal backer, Masyoshi Son, whose investment was protected in the form of millions of dollars if the WeWork IPO failed to reach its lofty goals - creating a conflict between him and other shareholders.

${ }^{138}$ Pollman, supra note 4.
} 
noting that he had "stayed silent too long." And that he would tolerate "[n]o more fantasies." 139 According to the Wall Street Journal, Schwartz and his fellow directors had "stayed silent so long that the story was almost over." 140 In doing so, the directors enjoyed the privilege of private status, doomed the company's IPO, and failed to adhere to their fiduciary duties.

Neumann, who was no longer CEO, was present at that board meeting; yet, when CEO, he rarely attended board meetings -- presumably, because he controlled the decisions anyway. Yet, allowing him to skip meetings was a failure on the board's part. So, why was he there this time? Because WeWork was "perilously low on cash after years of freewheeling spending" and was the "butt of jokes on Wall Street." 141 Despite receiving almost $\$ 40$ billion in cash over the years, arguably a powerful misallocation of capital, at the date of the board meeting, the hoped for IPO had crashed and burned, and the company had only a few weeks of funds left.

To be sure, the directors repeated silence was a governance failure. Indeed, the failure of the people and entities on which the privilege of private ordering was bestowed and the resulting failure of culture was enabled by board members and investment bankers, all of whom failed to engage. ${ }^{142}$ This board, like those of other corporate adolescents, was comprised of investor representatives with negotiated roles. From Softbank, which, through Masayoshi Son, urged Neumann to spend with abandon, to the venture capitalists who did not raise or push issues, the board members failed to fulfill their fiduciary duties. The gatekeeper bankers, of course, were not on the board, and they funded the choices, supporting Neumann, championing the company, and hoping for the chance to do the IPO - at least until publicness intervened. ${ }^{143}$ And, everyone joined in the adolescent culture, enabling the culture of conflicts to grow unchecked. ${ }^{144}$

Consider the conflicts and related party transactions listed in the prospectus and detailed in Part III. The WeWork offering documents stated

\footnotetext{
${ }^{139}$ Farrell and Brown, supra note 92.

${ }^{140}$ Farrell and Brown, supra note 92.

${ }^{141}$ Farrell and Brown, supra note 92.

${ }^{142}$ The funding and growth processes were fraught with conflicts of interest on all sides, and as the investors "ceded control," the company spun out of control missing projections - year after year.Farrell and Brown, supra note 92.

${ }^{143}$ Farrell and Brown, supra note 92.

${ }^{144}$ Consider, John Zhao, from Hony Capital, who invested after doing tequila shots with and being sprayed with a fire extinguisher by Neumann. Farrell and Brown, supra note 92 .
} 
that all were approved by the board, but after reading about how the board operated and its culture of silence, one wonders what really happened with each conflict. Indeed, the fact that many of the directors had conflicts of their own presumably embedded a you-scratch-my-back-I'll-scratch-yours culture that lowered the threshold for discourse and candor and enabled Neumann's ongoing conflicts. Who wants to engage in deep scrutiny of another's conflict when it might result in greater scrutiny of your own? Moreover, as Part II revealed, the motivations of the board members are at best mixed even before the culture of conflicts becomes embedded. Here, the result was the failure to examine and recognize privilege, the failure to understand the choices, and the failure of the IPO..$^{145}$

Notably, without affirmative approval by disinterested directors or shareholders, corporate law once would have declared many of the WeWork conflicts void and now views them as voidable. Yet, there are no "disinterested" or independent directors in today's startups. ${ }^{146}$ Even if they are not implicated in the Neumann-specific transactions and thus conflicted in the traditional sense, the behavior of the WeWork directors reveals that they viewed their role as enablers of the choices and were unwilling or incapable of playing the role corporate law prescribes. Indeed, conflicted themselves, they did not question the choices or give voice to concerns; instead, enjoying the privileges of the private offering regime and engaging in the very fiduciary deficits corporate law is designed to prevent.

\section{B. The Nature of Candor, Discourse, and Good Faith}

Traditionally, the role of venture capitalists on startup boards was perceived as providing a strong guiding hand to get the company to maturity. ${ }^{147}$

145 See also Donald C. Langevoort, Disasters and Disclosures, 107 Geo. L. Rev 967 (2018)(analyzing how transparency and disclosure decrease in the face of when companies experience downturns).

${ }^{146}$ See Michael Ewens \& Nadya Malenko, Board Dynamics Over the Startup Life Cycle, NBER Working Paper No. w.277769 (Sept. 2020) (providing evidence of timing and role of independent directors in start-ups and opining on their potential as mediators and advisors). 147 The conventional view of venture capitalists on start-up boards, with which we do not take issue, received considerable scholarly attention - but mostly before the more recent growth in private funding rounds. For articles exploring that view, see, e.g., Jesse M. Fried \& Mira Ganor, Agency Costs of Venture Capitalist Control in Startups, 81 N.Y.U. L. Rev. 967, 990 (2006) (lauding VCs on the board as able to control entrepreneur opportunism, monitor operations, and if necessary, implement new management); see also Brian Broughman \& Jesse M. Fried, Carrots and Sticks: How VCs Induce Entrepreneurial Teams to Sell Startups, 98 Cornell L. Rev. 1319, 1329 n. 39 (2013). 
Yet, the dialogue and engagement necessary to effect that was missing at WeWork. Also seemingly missing were conversations about conflicts and whether they should be avoided, or the question-asking, dialogue-building role that would allow the directors to vet risks and challenge management's understanding of its own role, choices, and privileged status.

Indeed, the power of good faith discourse is that it has the power to alter choices - and that is its purpose. ${ }^{148}$ It can reaffirm initial choices, and that is also its purpose. Both outcomes are examples of the power of the informationforcing-substance theory in action. Both are also examples of active and engaged decision making ${ }^{149}$ - the opposite of staying silent and feeding fantasies. And, they are examples of good faith in application and the creative friction that boards are supposed to provide and is their value. The goal is the conversation, the dialogue, the discourse, and the substance it produces.

Corporate directors, even those adhering to the proverbial nose-infingers-out line, are required to engage in monitoring and oversight. ${ }^{150}$ This fiduciary duty is at the core of the good-faith obligation rooted in the duty of loyalty. Staying silent was not Mark Schwartz's role - nor was it the role of any of the other directors. In doing so, they presumably failed to make conscious choices - a precondition for the application of the business judgment rule. ${ }^{151}$ They also presumably violated their duty of care and arguably failed to act in the face of problematic information, a hallmark of bad faith, which when sustained violates good faith. ${ }^{152}$

\footnotetext{
148 See Hillary A. Sale, Disclosure's Purpose, 107 Geo. L.J. 1045 (2019); see also Robert B. Thompson \& Hillary A. Sale, Securities Fraud as Corporate Governance: Reflections upon Federalism, 56 Vand. L. Rev. 859 (2019).

${ }^{149}$ See Hillary A. Sale \& Donald C. Langevoort, "We Believe”: Omnicare, Legal Risk Disclosure and Corporate Governance, 66 Duke L.J. 763, 788 (2016) (discussing the information-forcingsubstance theory and how dialogue can result in either a different outcome or the same outcome and both reflect active decision-making).

${ }^{150}$ Hillary A. Sale, Monitoring Caremark's Good Faith, 32 DEL. J. CORP. L. 719, 729 (2007).

${ }^{151}$ Smith v. Van Gorkom, 488 A.2d 858, 863 (Del. 1985). See also Aronson v. Lewis, 473 A.2d 805,812 (Del. 1984) (noting that the business judgment rule presumes that directors "acted on an informed basis, in good faith and in the honest belief that the action taken was in the best interests of the company").

${ }^{152}$ Stone v. Ritter, 911 A.2d 362, 370 (Del. 2006) ("Where directors fail to act in the face of a known duty to act, thereby demonstrating a conscious disregard for their responsibilities, they breach their duty of loyalty by failing to discharge that fiduciary obligation in good faith.”).
} 
Of course, corporate law has the ability to sanction bad faith via derivative litigation, and deception via the duty of candor. But these are notoriously difficult to prove. Delaware courts have carved out room for a disloyalty claim for exit transactions that favor preferred stockholders (i.e., funders) over founders and employees who hold options, signaling that directors cannot simply claim loyalty to those shareholders responsible for their appointment to the board. But this "Trados" line of cases has been heavily criticized by academics as inefficient and unrealistic, ${ }^{153}$ and in any event has not been extended to oversight or monitoring. The natural human inclination to represent one's principal is hard to overcome. Independent directors have persuasively been characterized as there mainly to play a mediator role, limiting their involvement unless needed to referee a dispute between founders and funders. This enables avoidance when the primary constituents are at peace, which is likely when the start-up has momentum.

There are also practical reasons to doubt that litigation will produce an optimal level of attentiveness, whether state or (as to fraud) federal. ${ }^{154}$ There are many reasons for this result, including, for example, the ratchet provision protecting Mayoshi, and as Elizabeth Pollman points out, the contracts and other provisions investors build in to protect themselves. Further, in the case of WeWork, we know that T. Rowe Price, a key institutional investor, recouped its earlier stage investment in a later round while making clear that it was disgusted by the company's antics. That ability to recoup, however, also decreases the likelihood of litigation. Conflicts of interest may arise as well portfolio managers may hesitate to sue well-established VC's and other early investors because the result might be exclusion from future opportunities.

\footnotetext{
153 See Pollman, supra note 4; Sarath Sanga \& Eric Talley, Don't Go Chasing Waterfalls: Fiduciary Duties in Venture Capital-backed Startups, Oct. 31, 2020, available at https://papers.ssrn.com/sol3/papers.cfm?abstract id=3721814.

${ }^{154}$ For doubts about litigation, see Verity Winship, Private Company Fraud, U.C. Davis L. Rev. (forthcoming, 2020); Pollman, supra note 2. To their concerns, we would add some additional points. If it is indeed true that $\mathrm{VCs}$ and other early funders want to avoid too much potentially troubling information even when represented on the board, this might result from - or be motivated by - a desire to avoid the scienter required under Rule 10b-5 in suits brought by later arrivals to the funding party. In many jurisdictions, sophisticated purchasers of securities can lose their fraud remedy - even when lied to about material facts - if they failed to do due diligence, a considerable (and perhaps reputation-tainting) possibility when financing rounds are done quickly and many investors want in on the action. Conflicts of interest may arise as well — portfolio managers may hesitate to sue well-established VCs and other early investors if it might result in being excluded from future opportunities. See also supra note 4 .
} 
The challenge in WeWork and other unicorn adolescents is that the privilege of private status was not designed for companies that stay "private" for as long as or of the size of WeWork. It was designed with the idea that sophisticated investors, including venture capitalists and banks, would invest in the companies, perform gatekeeping functions, nurture the companies, and allow the public regime, including its powerful litigation remedies, to take over. ${ }^{155}$

This, then, is where the system failed. The private offering regime has layered on privileges for adolescents incapable of managing the business, particularly long term, let alone navigating lines related to legality. The mythology has fueled spectacular growth and equally spectacular failures, making money for venture capitalists, banks, and money managers, but without asking the corporate adolescents or their funders to adult up. The result is the misallocation of capital, risky choices, and spillovers to downstream investors and stakeholders. ${ }^{156}$

In the end, WeWork failed to sustain it massive valuation in ways that seem to have confounded regulators, policy makers and the academics. The companies evolved, but private governance aspirations failed to do so. The system simply is not designed for long-term "startup" governance, and WeWork reveals the systemic slack and flaws. The "fix" requires some of the myth busting we have attempted in this article and understanding that the system is not nearly perfect. The reliance on reputational capital, if appropriate a decade ago, is no longer so. ${ }^{157}$ Indeed, assuming that conflicts and fiduciary deficits are unsolvable or always beneficial produces WeWorks. When the adults in the room are not accountable for the adolescents, candor, discourse, and good faith don't stand a chance: there is no internal control system to

\footnotetext{
${ }^{155}$ Compare Fried \& Ganor, supra note 147 (stating "[s]tartup boards - unlike public company boards - are also frequently and intimately involved in strategic decision making and personnel issues.") with Lerner \& Nanda, supra note 3, at 252 (emphasizing the rise of founder friendly behavior and the pressure for VCs not to be overbearing). See also Ewens \& Malenko, supra note 146 (discussing the fall of VC majority board control from $60 \%$ in 2002 to $25 \%$ for startups originated in 2013).

${ }^{156}$ Yusuf Khan, WeWork is reportedly cutting 2,000 jobs as soon as this week, with the staff turning against Adam Neumann, MARKETS INSIDER (Oct. 15, 2019) https:/ / markets.businessinsider.com/news/stocks/wework-reportedly-cutting-2000jobs-staff-turning-on-ceo-adam-neumann-2019-10-1028598379\#.

${ }^{157}$ See Fried \& Gordon, supra note 79 (discussing VC's fascination with brand name, latestage, hot startups to list on their portfolio pages, which in turn fuels overpayment for startups).
} 
prevent fiduciary deficits. When fiduciary obligations fail to grow with the funding rounds, the need for an increased focus on risk and its consequences is ignored. ${ }^{158}$ Yet, as a company's reach grows, the range of harm also expands, allowing failures that impact many more people and stakeholders than simply the venture capitalists and investment banks. ${ }^{159}$

\section{CONCLUSION}

Drawing from the WeWork saga and academic research about changing motivations, incentives and opportunities in start-up financing, we see an accumulating set of deficits that makes the current state of affairs more problematic than the conventional account would suggest:

(1) Founder control is more likely, enabling more sustained selfcentered and biased behaviors that, even if adaptive to an extent, produce risky behaviors among those not able to handle the glorification or freedom.

(2) The market for funding is more crowded, with private equity and venture finance being offered by a wider range of funders who have diverse incentives driven by the opportunities for fees and new funding opportunities before earlier investments pan out or not. As such, agency cost issues are present not simply at the level of the start-up, but upstream to the relationship between funders and their own (increasingly diverse and not always sophisticated) sources of capital.

(3) Start-up valuations are set in a market lacking many of the mechanisms of efficiency and subject to a winner's curse, which plays into these upstream and downstream incentives and biases. As a result of all the foregoing, fiduciary and information-forcing norms weaken.

(4) Directors focus on constituent protection or conflict mediation in exercising whatever power they possess, rather than attending in good faith to their duties of candor, care and loyalty.

\footnotetext{
${ }^{158}$ Langevoort \& Thompson, "Publicness" supra note 4 (describing the need for two distinct tiers of companies within securities regulation: first, those with a large societal footprint for which "full publicness treatment should be reserved" and second, smaller companies needing only core disclosure obligations and governance requirements.)

${ }^{159}$ Langevoort \& Thompson, "Publicness" supra note 4 (highlighting how the fall of companies such as Enron and WorldCom damages shareholders and debt holders, and employees, retirees, and competitors, and cause distortions in the market in which they operate).
} 
These deficits combine with the fast-growing flow of money into start-up financing to enable a longer period of undisciplined corporate adolescence during which the misbehavior risk rises, threatening investors and others

That is as far as we will go here. What to do about all of this is a hard question; we recognize, for example, that expansive disclosure requirements are not necessarily well suited for start-ups pursuing innovative strategies. However, we are convinced that the more dark space we afford start-ups and funders in the name of innovation, the more important it is for there to be good governance to oversee how that freedom is being used and to lessen the fiduciary deficits exhibited in the WeWork story and elsewhere. Maybe the better policy is to nudge start-ups toward a quicker IPO, with at least some of the rites of passage. ${ }^{160}$ At least then disclosure and publicness have the potential to shed light on the private choices of funders and founders. ${ }^{161}$

We are more confident as to what not to do, but is happening rapidly. For much of its history, as noted earlier, securities regulation sought to limit access to the private markets to qualified investors presumed able to fend for

160 Other regulatory reforms associated with the JOBS Act simplified the IPO process for emerging growth companies, which produced a step-up in biotech capital formation and accompanying innovation. See Craig Lewis \& Joshua White, Deregulating Innovation Capital: The Effect of the JOBS Act on Biotech Start-ups, Aug. 2020, available at https://papers.ssrn.com/sol3/papers.cfm?abstract_id=3640852. But see Coffee, supra note 80 .

161 From a policy perspective, there is good reason to consider tweaking the law if only to lessen the negative externalities of start-up misbehavior on others. Private issuers attract capital from investors in a competitive market including a wide range of opportunities; misinformation or other deficits result in a misallocation of capital, distorting investment choices and harming non-cheating firms competing for capital based on the bona fide qualities of their ideas. See, e.g., Elizabeth de Fontenay, The Deregulation of Private Capital and the Decline of the Public Company, 68 Hastings L.J. 445 (2017); Langevoort \& Thompson, "Publicness" supra note 4. The misallocation in turn adversely affects labor markets (especially when, as in the tech field, equity-based compensation is so common), among others. See Yifat Aran, Making Disclosures Work for Start-up Employees, 2019 Colum. Bus. L. Rev. 867; Jennifer Fan, Employees as Regulators: The New Private Ordering in High Tech Companies, 2019 Utah L. Rev. 973. This is the main reason we, like others, would favor moving public company status and the attendant governance obligations to a somewhat earlier phase in the successful start-up's adolescence, once the basic science or technology is in place and before its footprint on society grows deeper and deeper. 
themselves, a category that has expanded slowly but surely in recent decades. ${ }^{162}$ In the JOBS Act of 2012, Congress gave a boost to the effort by making it easier to prospect for such accredited investors. While this was often portrayed in terms of allowing start-ups to find a greater number of investors, the main effect was to give investment intermediaries (e.g., hedge funds) greater ability to attract capital to invest under its portfolio management, exacerbating the upstream agency cost problem and diminishing the ability of conventional VCs to dampen adolescent impulses.

This effort accelerated considerably in 2019, when the SEC announced its intention to enlarge the size of the retail investor population entitled to cross the wall and participate in private investment. ${ }^{163}$ The category of accredited investors was soon enlarged, and more reforms adopted in late fall 2020. The Commission doubled down on the strategy by proposing exemptive 212 relief from broker-dealer status to those who hustle to find accredited investors for private offerings. ${ }^{164}$ The Department of Labor joined the deregulation party with its own ERISA-based directive to allow retirement savings of accredited investors to move more heavily in alternative private investments. The "equity" claim that they deserve comparable investment opportunities to those now limited to the relatively privileged few comes through loud and clear. There is no reason, however, to believe that retail investors newly introduced into this space will find comparable opportunities to those afforded truly sophisticated, experienced players who can lean in against agency costs in how their money is invested. Rather, these new investors will find their way to market segments where salesmanship and marketing savvy abound and then overpay in search of already picked-over chances. How well upstream investors fend for themselves remains to be seen: we know much too little. Yet the regulatory movement is

\footnotetext{
${ }^{162}$ See Langevoort \& Thompson, "Publicness" supra note 4. Once based on subjective factors like genuine sophistication and ready access to information, the scope of the exemptive philosophy has become more objective over time: today, financial status (more than $\$ 1$ million in assets, or more than $\$ 200,000$ in annual income, with a variety of adjustments) sets the basic threshold, with a higher level of wealth ( $\$ 5$ million in investible assets) needed to invest in high performance fee-paying entities in the private capital markets, like hedge funds. Less well-off investors, as we have seen, can enter the private investment realm, but for the most part, only through a willingness to invest through more heavily regulated mutual funds and similar vehicles.)

${ }^{163}$ Concept Release on Harmonization of Securities Offering Exemptions, Rel. 33-10649, Sept. 24, 2019. Some rules have already been amended. See Amending the Accredited Investor Definition, Rel. 33-10824, Aug. 26, 2020); Facilitating Capital Formation and Expanding Opportunity by Improving Access to Capital in Private Markets, Rel. 33-10844, Nov. 2, 2020).

164 Exemptive Relief Under Section 15(a), Rel. 34-90112, Oct. 7, 2020.
} 
to open the private markets to more retail investors, ignoring the costs of the fiduciary deficits and, instead, relying on the myth of corporate adolescence, the infatuation with innovation, and the winning lottery tickets for those who get in the game early enough.

Why the politics of entrepreneurial capital-raising are tilting this way is a complicated question. No doubt much of what is pushing this is pure special interest muscle, which is a good reason by itself for legal academics to take more of an interest in the subject. The inspiring narratives about start-ups as drivers of innovation and job creation, geniuses who promise to invent us a better future, and the potential "equal playing field" created by allowing more retail investors into a space heretofore reserved for the already over-privileged all enable corporate adolescence.

Our cautionary note here, then, is not that innovation is an unworthy goal compared to investor protection, but simply that the assessment should be a sober one. High-tech innovation, after all, has decidedly mixed effects on employment, destroying jobs at incumbent firms without necessarily creating a comparable number of new ones. Some researchers believe that we are facing a time of harder-to-find good technological ideas, ${ }^{165}$ meaning that the money chasing the best ideas will face greater risk of disappointment on average and a winner's curse as to financing the occasional breakthroughs. Meanwhile, the fees keep coming to the money managers. There is reason to question the assumption that the system of entrepreneurial finance we've chosen is necessarily the best - or fairest - at allocating capital to the most socially productive ideas. ${ }^{166}$ Thus, the payoff from telling stories like WeWork, and of coming to better understand ever-changing incentives for rent-seeking inside that system, is that we expose the adolescent culture of conflicts and fiduciary deficits and put away the rose-colored glasses when deciding what is best going forward.

\footnotetext{
${ }^{165}$ See Nicholas Bloom et al., Are Ideas Getting Harder to Find?, 110 Am. Econ. Rev. 1104 (2020). Even a decade ago, there was some recognition that venture capital is less "scalable" than private equity generally. See Andrew Metrick \& Ayako Yasuda, The Economics of Private Equity Funds, 23 Rev. Fin. Stud. 2303 (2010).

${ }^{166}$ Lerner \& Nanda, supra note 3. See also Nathan Heller, Is Venture Capital Worth the Risk?, The New Yorker, Jan. 27, 2020.
} 